\title{
Biogenic Synthesis of Silver Nanoparticles (AgNPs) using Solanum indicum Linn.
}

\author{
Sadeq Khalid Alhag ${ }^{1,2}$, Hamed Ali Ghramah ${ }^{3,4}$, Lamya Ahmed Al-keridis ${ }^{5}$, Fahd Abdu Al-Mekhlafi ${ }^{6,7, *}$, \\ Essam Hassan Ibrahim ${ }^{3,8,9}$, Khalid Ali Khan ${ }^{3,10}$
}

${ }^{1}$ Biology Department, College of Science and Arts, King Khalid University, Muhayl Asser, SAUDI ARABIA.

${ }^{2}$ Biology Department, College of Science, Ibb University, YEMEN.

${ }^{3}$ Biology Department, Faculty of Science, King Khalid University, P.O. Box 9004, Abha 61413, SAUDI ARABIA.

${ }^{4}$ Research Center for Advanced Materials Science (RCAMS), King Khalid University, P.O. Box 9004, Abha 61413, SAUDI ARABIA.

${ }^{5}$ Department of Biology, Faculty of Science, Princess Nourah bint Abdulrahman University, Riyadh, SAUDI ARABIA.

${ }^{6}$ Bioproducts Research Chair, Department of Zoology, Faculty of Science, King Saud University, SAUDI ARABIA.

${ }^{7}$ Department of Agricultural Production, College of Agriculture and Veterinary Medicine, Thamar University, YEMEN.

${ }^{8}$ Research Center for Advanced Materials Science (RCAMS), King Khalid University, P.O. Box 9004, Abha 61413, SAUDI ARABIA.

${ }^{9}$ Blood Products Quality Control and Research Department, National Organization for Research and Control of Biologicals, Cairo, EGYPT.

${ }^{10}$ Unit of Bee Research and Honey Production, Faculty of Science, King Khalid University, P.O. Box 9004, Abha 61413, SAUDI

ARABIA.

\begin{abstract}
Background: Synthesis of silver nanoparticles (AgNPs) using green plants is important for biocompatibility, reduced hazards, green policy and eco-friendliness. Materials and Methods: In this study, a leaf extract of Solanum indicum and associated AgNPs were used to examine larvicidal properties and other biological activities. AgNP forms were characterized with scanning electron- microscopy (SEM), Fourier Transform Infrared Radiation spectroscopy (FTIR) and UV-vis spectra. Larvicidal activity was assessed with Culex pipiens larvae using the World Health Organization method. Antibacterial potential of $S$. indicum leaf extract and AgNPs were evaluated with a well diffusion assay. In vitro impacts of $S$. indicum extract and AgNPs were studied using spleen cell propagation. Results: $S$. indicum ethanol extract and associated AgNPs show larvicidal activity against $4^{\text {th }}$ instar of $C x$. pipiens. Synthesized AgNPs were more toxic, with lower lethal concentration values, $\left(\mathrm{LC}_{50}=47.181 \mathrm{ppm} ; \mathrm{LC}_{90}=243.776 \mathrm{ppm}\right)$ compared to plant extract $\left(\mathrm{LC}_{50}=131.448 \mathrm{ppm} ; \mathrm{LC}_{90}=4397.528 \mathrm{ppm}\right)$ after a twenty-four hour of exposure. Synthesized AgNPs also show significant impact Staphylococcus aureus, Proteus mirabilis, Escherichia coli and Shigella flexneri. Cytotoxic effects were demonstrated for $S$. indicum extract and AgNPs on normal spleen cells. The extract and associated AgNPs were also safe for red blood cells (RBCs) and failed to cause substantial elevation in serum liver enzymes. Conclusion: Leaf extracts of $S$. indicum and associated AgNPs may be efficient and eco-friendly for control of $C x$. pipiens. Their antibacterial activity may be useful if care is taken to prevent cytotoxic effects.
\end{abstract}

Key words: Cytotoxic effect, Culex pipiens, Silver Nanoparticles, Antibacterial, Larvicidal, Solanum indicum.

\section{INTRODUCTION}

Design and synthesis of nanoparticles is a promising area of research for physics, electronics, biotechnology, medicine, chemistry, catalysis and material sciences. Nanoparticles display many attractive physical-chemical features. ${ }^{1,2} \quad$ Silver nanoparticles (AgNPs) specifically are identified for multiple uses in medicine and biotechnology. ${ }^{3}$ Recently, substantial progress for synthesis of AgNPs using green extracts or essential oils. Plant extracts can be important for mosquito control factor since they may be ecologically suitable for use as larvicides. Green extract are generally recognized as eco-friendly agents for insect control. ${ }^{4}$ Mosquito control necessitates new
Submission Date: 03-06-2020; Revision Date: 08-10-2020; Accepted Date: 18-12-2020

DOI: 10.5530/ijper.55.1s.51 Correspondence: Dr. Fahd A Almekhlafi Associate Professor of Entomology, Bioproducts Research Chair, Department of Zoology, College of Science, King Saud University, Riyadh-11451, SAUDI ARABIA.

Phone: +966 0114699662 Email id: falmekhlafi@ksu. edu.sa

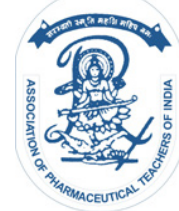

www.ijper.org 
and improved control approaches that are low-cost, ecofriendly and harmless to non-target animals. ${ }^{5}$ Biogenic forms of NPs from green extracts meet these criteria as an appropriate alternative for control of mosquito larvae. ${ }^{3}$ Nanoparticles display larvicidal properties that, in many cases, are better than properties of plant extracts used for synthesis. The combination of extracts and $\mathrm{AgNPs}$ may be more effective than other chemical larvicides. Biogenic AgNPs may also be useful for targeting bacteria because of their small size. ${ }^{6}$ Several research papers are available that focus on the synthesis of AgNPs using plant extracts. For instance, Tamarindus india and T. graveolens in the family Fabaceae, ${ }^{7,10}$ Aloe vera in the Asphodelaceae, ${ }^{8}$ and Emblica officinalis in the Phyllanthaceae. ${ }^{9}$

Moreover, antimicrobial properties of AgNPs are recognized against both viruses ${ }^{11}$ and bacteria. ${ }^{12}$ AgNPs have a highly particular region than their volume which prompts a great antimicrobial activity as compared with bulk Ag metal. ${ }^{13} \mathrm{~S}$. indicum is a widely distributed plant existing throughout India, Nepal, China and the Arab region. It is used for treatment of many diseases. Pharmacology and phytochemistry $S$. indicum was recently reviewed. ${ }^{14}$ The review highlights the potential of this plant as a source of alternative medicine. Bioactive compounds in $S$. indicum are responsible for its substantial therapeutic efficacy. ${ }^{15}$

The current study examined larvicidal efficiency, antibacterial action and cytotoxicity of AgNPs synthesized biogenically using a leaf extract of Solanum indicum. The structure of the NPs was evaluated with UV-VIS spectroscopy and volume and form were imaged using Scanning Electron Microscopy (SEM).

\section{MATERIALS AND METHODS}

\section{Plant extract}

Fresh leaves of $S$. indicum were collected from Rejalalma Village, Abha, Asir Region, Saudi Arabia and washed three times with tap water, dried at $25^{\circ} \mathrm{C}$ and triturated into fine powder. Fifty grams of dried leaf powder was mixed with $500 \mathrm{~mL}$ of $70 \%$ ethanol. The suspension was left for three hours, filtered through Whatman no. 1 filter paper and the filtrate stored in brown airtight bottle at $10^{\circ} \mathrm{C} .{ }^{16}$ One gram of dried leaf powder dissolved separately with $100 \mathrm{~mL}$ of either $70 \%$ ethanol or acetone to prepare two $1 \%$ stock solutions. ${ }^{17}$

\section{Rearing of Cx pipiens}

A field strain of $C x$. pipiens was used. The parental strain was raised from wild larvae, collected from Wadi Bn Hashbal sites in Abha governorate, Saudi Arabia and maintained under laboratory conditions of $27 \pm 2{ }^{\circ} \mathrm{C}$ and $70 \% \pm 10 \%$ relative humidity with $14: 10$ light/dark cycle. Larvae were fed on a diet of fish food or dried bread powder and dried milk. ${ }^{18}$

\section{Synthesis and characterization of (AgNPs)}

With few exceptions, AgNPs were synthesized using the method of Ibrahim et al. ${ }^{19}$ One $\mathrm{mL}$ of $1 \mathrm{mM}$ (AgNO3) was added to $99 \mathrm{~mL}$ of $S$. indicum extracts. The $\mathrm{pH}$ value of the solution was adjusted to 7.0 using $0.1 \mathrm{M}$ sodium hydroxide. The formation of AgNPs was revealed by a color change. The suspension of biogenic AgNPs was examined with UV-vis spectra, wavelength 475-600 $\mathrm{nm}$ in a UV-3600 Shimadzu spectrophotometer at 1 $\mathrm{nm}$ resolution. The form of the shaped nanoparticles was examined using a SEM (JEM-1011Tokyo, Japan). ${ }^{20}$ Functional groups of the botanical extract and synthesized AgNPs were evaluated using a PerkinElmer Spectrum 2000 FTIR within a range of 600-4000 $\mathrm{cm}^{-1}$, a rate of 16 and a resolution of $4 \mathrm{~cm}^{-1}$.

\section{Larvicidal bioassay}

Larvicidal activity was estimated using the method of $\mathrm{WHO}^{21}$ with revisions described by Rahuman et al. ${ }^{22}$ Different concentrations in five replicates were prepared from S. indicum extract and extract containing AgNPs in plastic cups filled with tap water $(100 \mathrm{~mL})$. One cup per replicate was used as a negative control. Twenty-four $4^{\text {th }}$ instar larvae of $C x$. pipiens in each cup were incubated for $24 \mathrm{hr}$ at $27^{\circ} \mathrm{C}$ with a $16: 8 \mathrm{~h} \mathrm{light/dark} \mathrm{cycle.} \mathrm{Larval}$ deaths were documented $24 \mathrm{hr}$ post-treatment for the $S$. indicum extract and extract with AgNPs. Larvae were considered dead when failed to move after probing their siphon with a needle.

\section{Well diffusion method for antibacterial efficacy}

Escherichia coli, Shigella flexneri, Proteus mirabilis and Stapbylococcus aureus were used in this study. Nutrient agar and broth (HiMedia Laboratories Pvt. Ltd. India) were prepared by following manufacturer instructions to culture bacterial strains. Antimicrobial potential of $S$. indicum extract and its extract with AgNPs was evaluated by agar well diffusion following Ghramh et al..$^{23}$

\section{In vitro impacts of $S$. indicum extract and AgNPs on spleen cell propagation}

Spleens of healthy adult male Sprague Dawley rat weighing about $244 \mathrm{~g}$, kindly provided by the animal house at King Khalid University, were used to obtain spleen cells as described previously by Ibrahim et al..$^{19}$ Analysis of the results involved calculating percent increase and decrease in growth, as described previously by Oves et al..$^{24}$ inexpensive, and ecofriendly, therefore, 
are used preferably in industries, medical and material science research. Considering the importance of biofabricated materials, we isolated, characterized and identified a novel bacterial strain OS4 of Stenotrophomonas maltophilia (GenBank: JN247637.1

\section{Lytic impacts of $S$. indium extract and associated silver nanoparticles on (RBCs)}

The lytic impact of $S$. indicum leaf extract and associated silver nanoparticles were evaluated as described previously by Ibrahim et al..$^{19}$ The extract and AgNPs at concentrations of $1 \mathrm{mg} / \mathrm{mL}$ in sterile phosphatebuffered saline (PBS, pH 7.4) were prepared. A $150 \mu \mathrm{L}$ aliquot was added from the extract with AgNPs and the plant extract only to $850 \mu \mathrm{L}$ of prepared RBCs in $1.5 \mathrm{~mL}$ Eppendorf tubes and incubated for $60 \mathrm{~min}$ at $37^{\circ} \mathrm{C} .1 \%$ Triton $(\mathrm{X}-100)$ and phosphate buffer saline (PBS) was used as positive control and negative controls, respectively.

\section{Statistical analysis}

\section{Statistical analysis of larvicidal bioassay}

LSD compared means of larval mortality at $P \leq 0.05$ using SAS program while $\mathrm{LC}_{50}$ and $\mathrm{LC}_{90}$ regression equations were estimated using computerized log-probity analysis and LDP Line software.

\section{Statistical analysis of antimicrobial activity}

Antimicrobial activity was measured in terms of average $+/$ - standard deviation (SD) of three replicates ZOI measurements. One-way analysis of variance (ANOVA) used Statistix 8.1 software. All pairwise comparison of means was performed with Tukey's Honest Significant Difference test. Means differences of $p<0.05$ were considered statistically significant.

\section{RESULTS}

\section{Identification of AgNPs}

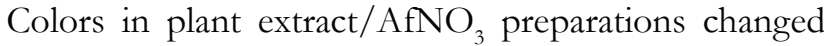
from dark yellow to black then to dark brown (Figure 1). The blackening of the brownish color occurs over time. Color changes were easily seen by visually.

S. indicum biogenic AgNPs were examined by UV-vis spectra after mixing with an aqueous solution of $\mathrm{AgNO}_{3}$. The electronic absorption spectrum of the extract before adding silver nitrate shows a broad absorption at $488 \mathrm{~nm}$. Electronic absorption spectra of AgNPs displays absorbency constructivism at $490 \mathrm{~nm}$ (Figure 2).

FTIR spectroscopy analyses were performed to identify bioactive components responsible for stabilizing of synthesized AgNPs using S. indicum. FTIR spectra of

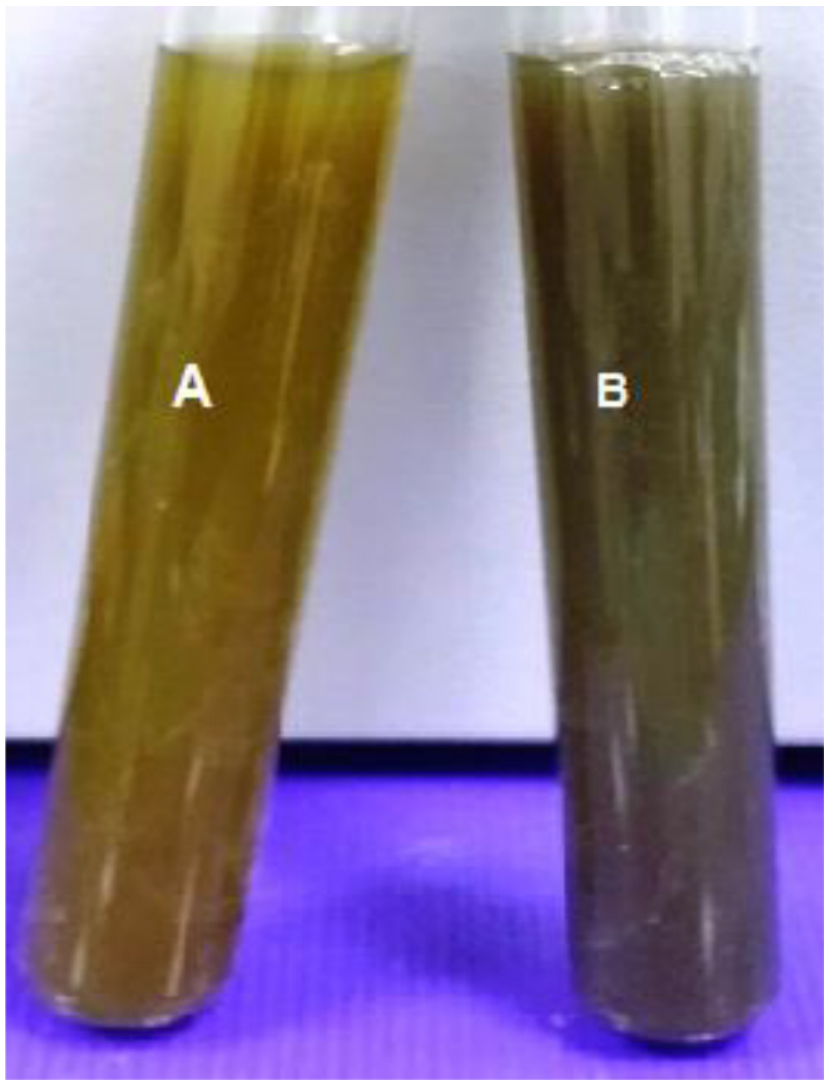

Figure 1: Change in color: $(A)$ before adding $\mathrm{AgNO}_{3}$ in S. indicum leaf ethanol extract and (B) after adding $\mathrm{AgNO}_{3}$ to $S$. indicum leaf ethanol extract.



Figure 2: UV-Vis spectra of silver nanoparticles synthesized by $S$. indicum leaf extract. Where (A) plant extract without $\mathrm{AgNO}_{3}$ and (B) plant extract with $\mathrm{AgNO}_{3}$.

silver nanoparticles showed a sharp vibrational band at $3350.87 \mathrm{~cm}^{-1}$ (Figure 3). A weak band was visualized at 2100.52-1949.21 $\mathrm{cm}^{-1}$ and a strong stretching band at $1650.23 \mathrm{~cm}^{-1}$. Weak bands were also observed at 1450.33 and $1327.40 \mathrm{~cm}^{-1}$.

SEM images of AgNPs show irregular and aggregated shapes with an average size of $70 \mathrm{~nm}$ with the distance between particles. These particles were magnified 30000 times (Figure 4.) 
Larvicidal activity of $S$. indicum extract and the extract contains $\mathrm{AgNO}_{3}$ against $\mathrm{Cx}$. pipiens larvae

At concentrations between 500 to 2500 and 50 to $250 \mathrm{ppm}$, respectively, extracts and extracts plus nanoparticles caused $72.727 \%$ to $89.899 \%$ and $53.535 \%$ to $94.949 \%$
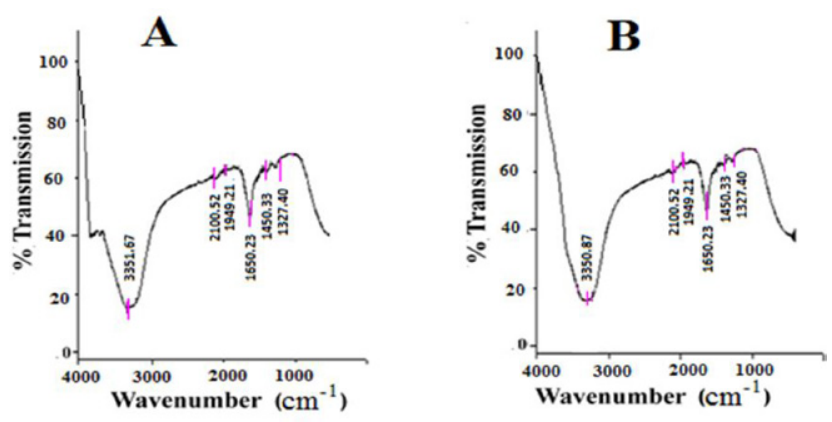

Figure 3: (A) Ftir spectra of S. indicum extract (B) S. indicum with AgNPs.

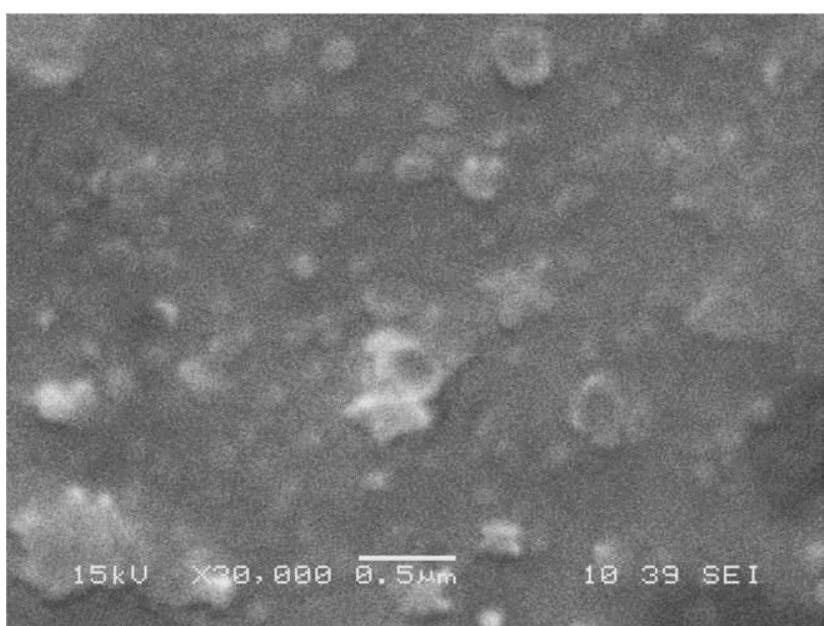

Figure 4: SEM image of silver nanoparticles in aggregated and irregular shapes. larva mortality, respectively (Table 1). With decreasing concentrations of nanoparticles, the mortality rate in $4^{\text {th }}$ instar larvae decreased. The extract of $S$. indicum with silver nanoparticles produced an $\mathrm{LC}_{50}(47.181 \mathrm{ppm})$ lower than the extract of $S$. indicum alone (131.448 ppm). The extract with nanoparticles was thus 2.786 times more potent (Figure 5).

\section{Antibacterial activity}

In vitro antibacterial potential of $S$. indicum leaf extract and associated AgNPs both inhibited growth of bacterial pathogens (Table 2). Average diameters of ZOI formed by $S$. indicum plant extract + AgNPs were statistically comparable $(p>0.05)$ with the positive control for $E$. coli and $S$. aureus but significantly different from positive controls and extract alone against Shigella flexneri and $P$. mirabilis $(p<0.05)$. Average diameters of ZOI formed by plant extract alone were statistically similar $(\phi>0.05)$ with positive controls against $P$. mirabilis and Shigella flexneri but were significantly different $(p<0.05)$ from positive controls against $E$. coli and $S$. aureus.

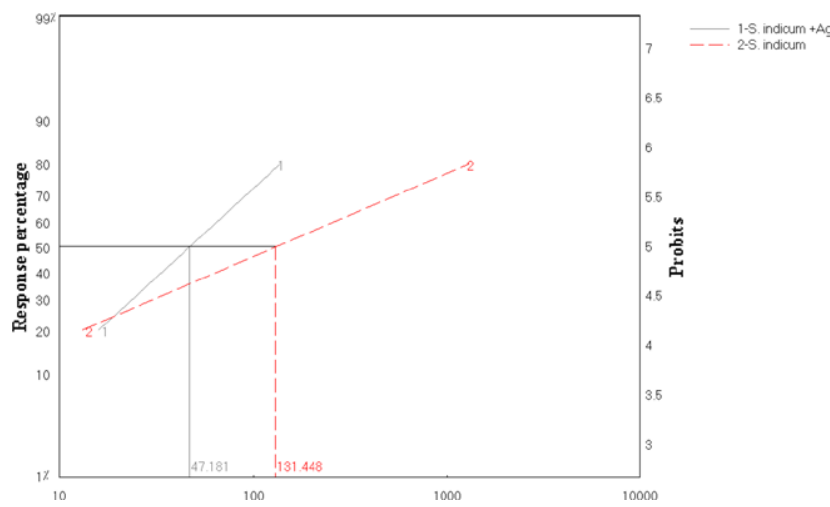

Figure 5: Dose-relationship between concentrations of plant extracts and mortality of $4^{\text {th }}$ instar larvae of $C x$. pipiens. Line 1: $\mathrm{S}$. indicum $+\mathrm{AgNo}_{3}$, Line 2: $S$. indicum.

Table 1: Susceptibility of Culex pipiens larvae to S. indicum and associated silver nanoparticles (AgNPs)

\begin{tabular}{|c|c|c|c|c|c|c|}
\hline Bioinsecticide & Conc. (ppm) & $\begin{array}{c}\text { Mortality }{ }^{a} \\
(\%)\end{array}$ & $\begin{array}{l}\text { LC }_{50} \text { (ppm) } \\
\text { (LCL-UCL) }\end{array}$ & $\begin{array}{l}\text { LC }_{90} \text { (ppm) } \\
\text { (LCL-UCL) }\end{array}$ & $\begin{array}{c}x^{2} \\
\text { d.f }(n . s)=4^{b}\end{array}$ & slope \\
\hline S. indicum & $\begin{array}{c}500 \\
1000 \\
1500 \\
2000 \\
2500 \\
0\end{array}$ & $\begin{array}{c}72.727 \\
72.727 \\
76.768 \\
84.848 \\
89.899 \\
1.33\end{array}$ & $\begin{array}{c}142.686 \\
6.9161-328.409\end{array}$ & $\begin{array}{c}4611.37 \\
2628.8-31647.9\end{array}$ & 4.7113 & 0.849 \\
\hline $\begin{array}{c}\text { S. indicum } \\
+ \\
\text { AgNo }_{3} \text { (AgNPs) }\end{array}$ & $\begin{array}{c}50 \\
100 \\
150 \\
200 \\
250 \\
0\end{array}$ & $\begin{array}{c}53.535 \\
72.727 \\
76.768 \\
84.848 \\
94.949 \\
1.33\end{array}$ & $\begin{array}{c}49.433 \\
34.199-62.300\end{array}$ & $\begin{array}{c}248.70 \\
199.81-350.65\end{array}$ & 4.727 & 1.826 \\
\hline
\end{tabular}

a: Five replicates, 20 larvae each

b. Tabulated $(\mathrm{Chi})=7.8$, larger than the calculated value for an 0.05 level of significance, indicates the line is fit well and data are homogenous. 


\begin{tabular}{|c|c|c|c|c|}
\hline \multicolumn{5}{|c|}{$\begin{array}{l}\text { Table 2: Antibacterial potential of } S \text {. indicum leaf } \\
\text { extract and extract with silver nanoparticles (AgNPs), } \\
\text { with } 1 \mathrm{mM} \text { concentration. }\end{array}$} \\
\hline \multirow{3}{*}{ 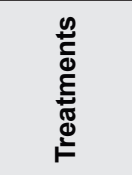 } & \multicolumn{4}{|c|}{ Zone of inhibition $(\mathrm{mm})$} \\
\hline & \multicolumn{4}{|c|}{ Bacterial strains } \\
\hline & $\begin{array}{l}\text { Escherichia } \\
\text { coli }\end{array}$ & $\begin{array}{l}\text { Proteus } \\
\text { mirabilis }\end{array}$ & $\begin{array}{c}\text { Staphylococcus } \\
\text { aureus }\end{array}$ & $\begin{array}{l}\text { Shigella } \\
\text { flexneri }\end{array}$ \\
\hline Extract & $\begin{array}{c}19.33 \pm \\
1.15^{\mathrm{b}}\end{array}$ & $\begin{array}{c}20.67 \pm \\
2.31^{b}\end{array}$ & $15.67 \pm 2.51^{b}$ & $\begin{array}{c}19.33 \pm \\
2.31^{\mathrm{b}}\end{array}$ \\
\hline $\begin{array}{c}\text { Extract + } \\
\text { AgNPs }\end{array}$ & $\begin{array}{c}21.33 \pm \\
2.31^{\mathrm{ab}}\end{array}$ & $\begin{array}{c}24.67 \pm \\
1.15^{\mathrm{a}}\end{array}$ & $19.00 \pm 3.61^{\mathrm{ab}}$ & $\begin{array}{c}28.00 \pm \\
2.00^{\mathrm{a}}\end{array}$ \\
\hline $\begin{array}{c}\text { Control } \\
\text { (Positive) }\end{array}$ & $\begin{array}{c}22.67 \pm \\
1.15^{\mathrm{a}}\end{array}$ & $\begin{array}{c}20.00 \pm \\
1.00^{\mathrm{b}}\end{array}$ & $21.00 \pm 1.00^{\mathrm{a}}$ & $\begin{array}{c}19.67 \pm \\
0.58^{\mathrm{b}}\end{array}$ \\
\hline
\end{tabular}

NB: Zones of inhibitions are expressed as the average of three replicates \pm SD. Means with same superscript letters are not significantly different.

\begin{tabular}{|c|c|c|}
\hline $\begin{array}{c}\text { Table 3: Effects of S. indicum leaf extract and extract } \\
\text { with AgNPs on normal rat spleen cells. }\end{array}$ \\
\hline \multirow{2}{*}{$(\mu \mathrm{g} / \mathrm{mL})$} & \multicolumn{2}{|c|}{$\%$ of spleen cells growth inhibition } \\
\cline { 2 - 3 } & $\begin{array}{c}\text { Solanum indicum } \\
\text { leaf extract }\end{array}$ & $\begin{array}{c}\text { Solanum indicum leaf } \\
\text { extract with AgNPs }\end{array}$ \\
\hline 200 & $63.50 \pm 2.50$ & $108.30 \pm 1.5$ \\
\hline 100 & $55.78 \pm 1.80$ & $85 . . \pm 1.20$ \\
\hline 50 & $49.87 \pm 1.86$ & $66.57 \pm 0.97$ \\
\hline
\end{tabular}

\begin{tabular}{|c|c|c|c|}
\hline No. & Treatment & $\begin{array}{c}\text { Absorbance at } \\
\text { wavelength of } \\
576 \mathrm{~nm}\end{array}$ & $\begin{array}{c}\text { RBC } \\
\text { hemolysis } \\
(\%)\end{array}$ \\
\hline 1 & Plant leaf acetone extract & $>3.00$ & 100 \\
\hline 2 & Plant extract with (AgNPs) & $>3.00$ & 100 \\
\hline 3 & Control (Negative) & 0.067 & 0 \\
\hline 4 & Control (Positive) & $>3.00$ & 100 \\
\hline
\end{tabular}

\section{Cytotoxic/proliferative effects}

S. indicum leaf extract and associated AgNPs were cytotoxic to normal spleen cells. The cytotoxic impact decreased with decreasing leaf extract and leaf plus AgNPS concentrations (Table 3). The extract without AgNPs showed less cytotoxicity.

\section{Lytic impacts of S. indicum extract and associated AgNPS on (RBCs)}

The cytotoxicity was studied by testing the hemolytic impacts on cow RBCs using a positive control (1\% Triton-X-100) and negative control (PBS). Hemolysis was measured by comparing the absorbance of the sample to negative and positive controls (Table 4 and Figure 6). 100\% lysis was observed in the positive control, while no lysis of RBCs was observed in the

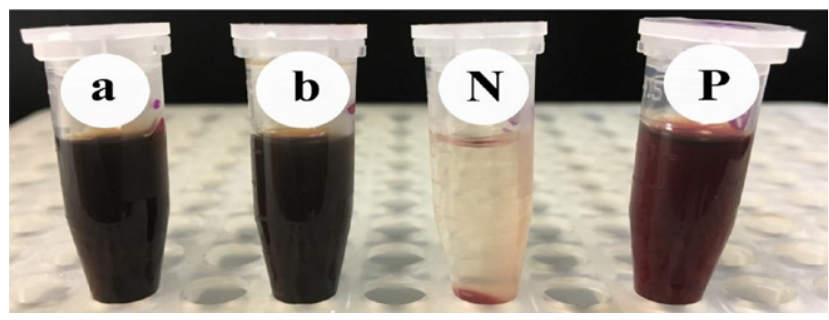

Figure 6: The effect of (a) S. indicum L. leaf acetone extract alone and (b) associated biosynthesized silver nanoparticles (AgNPs) on cow RBCs. Where, $\mathrm{N}$ is the negative control and $P$ is the positive control.

negative control (PBS). The lysis may be attributed to the effect of the NPs on RBCs' membranes. Other authors refer to the hemolytic effect as due to induced oxidative stress following exposure.

\section{DISCUSSION}

The distinctive brown color refers to the stimulation of exterior Plasmon Response with AgNPs as discussed in Ranganathan $e t a l^{25}$ This color transference is often evidence of changes in oxidation state where $\mathrm{Ag}^{+}$ is reduced to $\mathrm{Ag}^{0}$ in a reaction with $S$. indicum extract enzymes and nitrate. When the enzymes go out to the solution that can reduce the $\mathrm{AgNO}_{3}$ to AgNPs through covering agents like proteins. ${ }^{26} \mathrm{UV}$-vis spectra is extensively used for structural characterization of NPs. ${ }^{27}$ This method may respond to interactions of silver ions with biomolecules found in the leaf extracts. ${ }^{26,27}$ Ftir spectroscopy analyses of silver nanoparticles (Figure 3) show a sharp vibrational band at $3350.87 \mathrm{~cm}^{-1}$ that corresponds to the stretching $\mathrm{OH}$ band of alcohols. The weak bending band at $2100.52-1949.21 \mathrm{~cm}^{-1}$ may be attributed $\mathrm{C}-\mathrm{H}$ in aromatic compounds. The strong stretching band at $1275 \mathrm{~cm}^{-1}$ may correspond to $\mathrm{C}-\mathrm{O}$ in alkyl aryl ethers. The strong stretching band observed at $1650.23 \mathrm{~cm}^{-1}$ is assigned to $\mathrm{C}=\mathrm{O}$ attributed to $\delta$-lactam. Weak bands observed at 1450.33 and $1327.40 \mathrm{~cm}^{-1}$ may indicate the presence of $\mathrm{C}-\mathrm{H}$ and $\mathrm{O}-\mathrm{H}$ of alkanes and alcohols. ${ }^{28}$ SEM analysis shows a size and shape of AgNPs in $S$. indicum plant extract that may increase their toxicity to mosquito larvae. ${ }^{29}$ The extract of $S$. indicum with nanoparticles shows substantial activity against larvae of $C x$. pipiens consistent with reports from other authors. $^{30-32} \mathrm{~S}$. indicum extract and associated AgNPs showed a promising larvicidal potential against Aedes aegypti and Anopheles stephensi larvae. ${ }^{33}$ Generally, the blending of $S$. indicum extract with silver nitrate produces an agent more effective against larvae of $C x$. pipiens. Reduction of silver ion to elemental silver may be key to this activity. Compounds in the extract are likely linked to surfaces of the particles thus increasing their activity. ${ }^{34}$ 
The small size of particles likely also increases parricidal activity, consistent with the report by Rajasekharreddy and Rani declared. ${ }^{35}$

S. indicum leaf extract also displays antimicrobial activity against pathogenic bacteria (Table 1). The plant extract alone is an effective antibacterial and silver nanoparticles substantially increased activity against all tested bacteria. These results are consistent with other studies. ${ }^{36}$ examined the antimicrobial effects mentioned in ancient historical references of Ghanaian medicinal plant extracts, including Solanum sp., against bacteria. They found that extracts from the leaves of Solanum verbascifolium show antibacterial activity against several Gram-positive microbes. Antibacterial factors in Solanum sp. might include a phosphorylated purine. ${ }^{37}$ Similar results were reported by Sengottaiyan et al. ${ }^{38}$ who studied the antibacterial potential of $S$. indicum synthesized AgNPs against Staphylococcus sp. and Klebsiella sp. Antibacterial properties of AgNPs that are green synthesized by $S$. indicum may reflect their small size, leading to large surface areas. Thus, particle size may result in increased binding to bacterial cell walls, damage to cell walls and membrane-bound cellular enzymes, penetration through the cell membrane. ${ }^{39}$ Further, antibacterial effects may involve the interaction of AgNPs with thiol groups of L-cysteine residues in proteins, leading to enzymatic dysfunction. ${ }^{40}$ Also, AgNPs may encourage formation reactive oxygen species with resulting oxidative damage to cellular components, triggering cell death. ${ }^{41}$ Further, cytotoxicity to normal spleen cells caused by the extract alone is augmented when AgNPs are present. Similar results were obtained by Aravinthan et al..$^{42}$ and Sengottaiyan et al. ${ }^{38}$ where nanoparticles produced by the extract significantly reduced rat spleen cell viability in a dose-dependent manner. Several species of the genus Solanum have been assessed for their cytotoxicity in healthy and cancer cells. Raw extracts or compounds from Solanum spp. Inhibit proliferation of human and animal cells. ${ }^{43}$

This study confirm that extracts of $S$. indicum and associated nanoparticles display antimicrobial, cytotoxic, hemolytic and larvicidal activities.

\section{CONCLUSION}

This present study indicates that leaf extracts of $S$. indicum and associated biogenic AgNPs may be effective and eco-friendly for control of $C x$. pipiens larvae. They also display significant antibacterial activity. Caution is advised to prevent human contact since substantial cytotoxicity to normal spleen cells is observed.

\section{ACKNOWLEDGEMENT}

This research was funded by the Deanship of Scientific Research at Princess Nourah bint Abdulrahman University through the fast-track Research Funding Program.

\section{CONFLICT OF INTEREST}

The authors declare that there is no conflict of interest.

\section{REFERENCES}

1. Venkatpurwar V, Pokharkar V. Green synthesis of silver nanoparticles using marine polysaccharide: Study of in-vitro antibacterial activity. Mater Lett. 2011;65(6):999-1002.

2. Babu SA, Prabu HG. Synthesis of AgNPs using the extract of Calotropis procera flower at room temperature. Mater Lett. 2011;65(11):1675-7.

3. Albrecht M. Green chemistry and the health implications of nano-particles. Green Chem. 2006;8(5):417-32.

4. Rahuman AA, Bagavan A, Kamaraj C, Saravanan E, Zahir AA, Elango G. Efficacy of larvicidal botanical extracts against Culex quinquefasciatus Say (Diptera: Culicidae). Parasitol Res. 2009;104(6):1365.

5. Kamaraj C, Bagavan A, Rahuman AA, Zahir AA, Elango G, Pandiyan G. Larvicidal potential of medicinal plant extracts against Anopheles subpictus Grassi and Culex tritaeniorhynchus Giles (Diptera: Culicidae). Parasitol Res. 2009;104(5):1163.

6. Zayed MF, Eisa WH, Shabaka AA. Malva parviflora extract assisted green synthesis of silver nanoparticles. Spectrochim Acta Part A Mol Biomol Spectrosc. 2012;98:423-8.

7. Shankar SS, Rai A, Ahmad A, Sastry M. Rapid synthesis of Au, Ag and bimetallic Au core--Ag shell nanoparticles using Neem (Azadirachta indica) leaf broth. J Colloid Interface Sci. 2004;275(2):496-502.

8. Chandran SP, Chaudhary M, Pasricha R, Ahmad A, Sastry M. Synthesis of gold nanotriangles and silver nanoparticles using Aloevera plant extract. Biotechnol Prog. 2006;22(2):577-83.

9. Ankamwar B, Damle C, Ahmad A. Sastry M. Biosynthesis of gold and silver nanoparticles using Emblica officinalis fruit extract, their phase transfer and transmetallation in an organic solution. J Nanosci Nanotechnol. 2005;5(10):1665-71.

10. Shankar SS, Ahmad A, Sastry M. Geranium leaf assisted biosynthesis of silver nanoparticles. Biotechnol Prog. 2003;19(6):1627-31.

11. Lara HH, Ayala-Nuñez NV, Ixtepan-Turrent L, Rodriguez-Padilla C. Mode of antiviral action of silver nanoparticles against HIV-1. J Nanobiotechnology. 2010;8(1):1.

12. Sondi I, Salopek-Sondi B. Silver nanoparticles as antimicrobial agent: A case study on E. coli as a model for Gram-negative bacteria. Journal of Ccolloid and Interface Science. 2004;275(1):177-82.

13. Mahendra R. Silver nanoparticles as a new generation of antimicrobials. Biotechnol Adv. 2009;27(1):76-83.

14. Sharma V, Hem K, Seth A, Maurya SK. Solanum indicum Linn.: An ethnopharmacological, phytochemical and pharmacological review. Curr Res J Pharm Allied Sci. 2017;1(2):1-9.]

15. Syu WJ, Don MJ, Lee GH, Sun CM. Cytotoxic and novel compounds from Solanum indicum. J Nat Prod. 200164(9):1232-3.

16. Hamed GA, Jazem MA, Sadeq AK. Synthesis of Silver Nanoparticles from Schinus Molle extract and its larvicidal activity against Aedes aegypti (L.), the vector of dengue fever in kingdom of Saudi Arabia. Res J Biotechnol. 2018;13(5):63-70.

17. Ibrahim SK, Traboulsi AF, El-Haj S. Effect of essential oils and plant extracts on hatching, migration and mortality of Meloidogyne incognita. Phytopathologia Mediterranea. 2006;45(3):238-46.

18. Mahyoub JA, Alsobhi AS, Al-Ghamdi K. Effectiveness of seven mosquito larvicides against the West Nile vector Culex pipiens (L.) in Saudi Arabia. Asian Pacific J Trop Dis. 2016;6(5):361-5.

19. Ibrahim EH, Kilany M, Ghramh HA, Khan KA, UI Islam S. Cellular proliferation/ cytotoxicity and antimicrobial potentials of green synthesized silver 
nanoparticles (AgNPs) using Juniperus procera. Saudi Journal of Biological Sciences. 2018;26(7):1689-94.

20. Jyoti K, Baunthiyal M, Singh A. Characterization of silver nanoparticles synthesized using Urtica dioica Linn. leaves and their synergistic effects with antibiotics. J Radiat Res Appl Sci. 2016;9(3):217-27.

21. WHO. Report of the WHO Informal Consultation on the Evaluation and Testing of Insecticides W H O Geneva. 1996.

22. Rahuman AA, Gopalakrishnan G, Ghouse BS, Arumugam S, Himalayan B. Effect of Feronia limonia on mosquito larvae. Fitoterapia. 2000;71(5):553-5.

23. Ghramh HA, Khan KA, Alshehri AM. Antibacterial potential of some Saudi honeys from Asir region against selected pathogenic bacteria. Saudi Journal of Biological Sciences. 2018;26(6):1278-84

24. Oves M, Khan MS, Zaidi A. Antibacterial and cytotoxic efficacy of extracellular silver nanoparticles biofabricated from chromium reducing novel OS4 strain of Stenotrophomonas maltophilia. PLoS One. 2013;8(3):e59140.

25. Ranganathan R, Madanmohan S, Kesavan A, Baskar G, Krishnamoorthy YR, Santosham $\mathrm{R}$, et al. Towards development of patient-friendly drug-delivery systems for oncological applications. Int J Nanomedicine. 2012;7:1043-6.

26. Manivasagan P, Venkatesan J, Senthilkumar K, Sivakumar K, Kim SK. Biosynthesis, antimicrobial and cytotoxic effect of silver nanoparticles using a novel Nocardiopsis sp. MBRC-1. Biomed Res Int. 2013.

27. Sun YP, Atorngitjawat P, Meziani MJ. Preparation of silver nanoparticles via rapid expansion of water in carbon dioxide microemulsion into reductant solution. Langmuir. 2001;17(19):5707-10.

28. Umoren SA, Obot IB, Gasem ZM. Green synthesis and characterization of silver nanoparticles using red apple (Malus domestica) fruit extract at room temperature. J Mater Env Sci. 2014;5(3):907-14.

29. Ramesh S, Grijalva M, Debut A, Beatriz G, Albericio F, Cumbal LH. Peptides conjugated to silver nanoparticles in biomedicine--a value-added phenomenon. Biomater Sci. 2016;4(12):1713-25.

30. Ghosh A, Chowdhury N, Chandra G. Plant extracts as potential mosquito larvicides. Indian J Med Res. 2012;135(5):581.

31. Grzybowski A, Tiboni M, Silva MAN, Chitolina RF, Passos M, Fontana JD. Synergistic larvicidal effect and morphological alterations induced by ethanolic extracts of Annona muricata and Piper nigrum against the dengue fever vector Aedes aegypti. Pest Manag Sci. 2013;69(5):589-01.

32. Mahesh P, Kumar K, Murugan K, Kovendan J, Subramaniam DA. Mosquito larvicidal and pupicidal efficacy of Solanum xanthocarpum (Family:
Solanaceae) leaf extract and bacterial insecticide, Bacillus thuringiensis, against Culex quinquefasciatus Say (Diptera: Culicidae). Parasitol Res. 2012;110(6):2541-50.

33. Patil CD, Borase HP, Patil SV, Salunkhe RB, Salunke BK. Larvicidal activity of silver nanoparticles synthesized using Pergularia daemia plant latex against Aedes aegypti and Anopheles stephensi and nontarget fish Poecillia reticulata. Parasitol Res. 2012;111(2):555-62.

34. Borase HP, Patil CD, Salunkhe RB, Narkhede CP, Salunke BK, Patil SV. Phyto-synthesized silver nanoparticles: A potent mosquito biolarvicidal agent. J Nanomedicine Biother Discov. 2013;3(1):1-7.

35. Rajasekharreddy P, Rani PU. Biofabrication of Ag nanoparticles using Sterculia foetida L. seed extract and their toxic potential against mosquito vectors and HeLa cancer cells. Mater Sci Eng C. 2014;39:203-12.

36. Pesewu GA, Cutler RR, Humber DP. Antibacterial activity of plants used in traditional medicines of Ghana with particular reference to MRSA. J Ethnopharmacol. 2008;116(1):102-11.

37. Beaman-Mbaya V, Muhammed SI. Antibiotic action of Solanum incanum Linnaeus. Antimicrob Agents Chemother. 1976;9(6):920-4.

38. Sengottaiyan A, Mythili R, Selvankumar T, et al. Green synthesis of silver nanoparticles using Solanum indicum L. and their antibacterial, splenocyte cytotoxic potentials. Res Chem Intermed. 2016;42(4):3095-103.

39. Su HL, Chou CC, Hung D. The disruption of bacterial membrane integrity through ROS generation induced by nanohybrids of silver and clay. Biomaterials. 2009;30(30):5979-87.

40. Gordon O, Slenters TV, Brunetto PS, Villaruz AE, Sturdevant DE, Otto M, et al. Silver coordination polymers for prevention of implant infection: Thiol interaction, impact on respiratory chain enzymes and hydroxyl radical induction. Antimicrob Agents Chemother. 2010;54(10):4208-18.

41. Abdal DA, Hossain MK, Lee SB. The role of reactive oxygen species (ROS) in the biological activities of metallic nanoparticles. Int J Mol Sci. 2017;18(1):120.

42. Aravinthan A, Govarthanan M, Selvam K. Sunroot mediated synthesis and characterization of silver nanoparticles and evaluation of its antibacterial and rat splenocyte cytotoxic effects. Int J Nanomedicine. 2015;10:1977.

43. Nyeem MAB, Rashid AMU, Nowrose M, Hossain MA. Solanum nigrum (Maku): A review of pharmacological activities and clinical effects. IJAR. 2017;3(1):12-7.

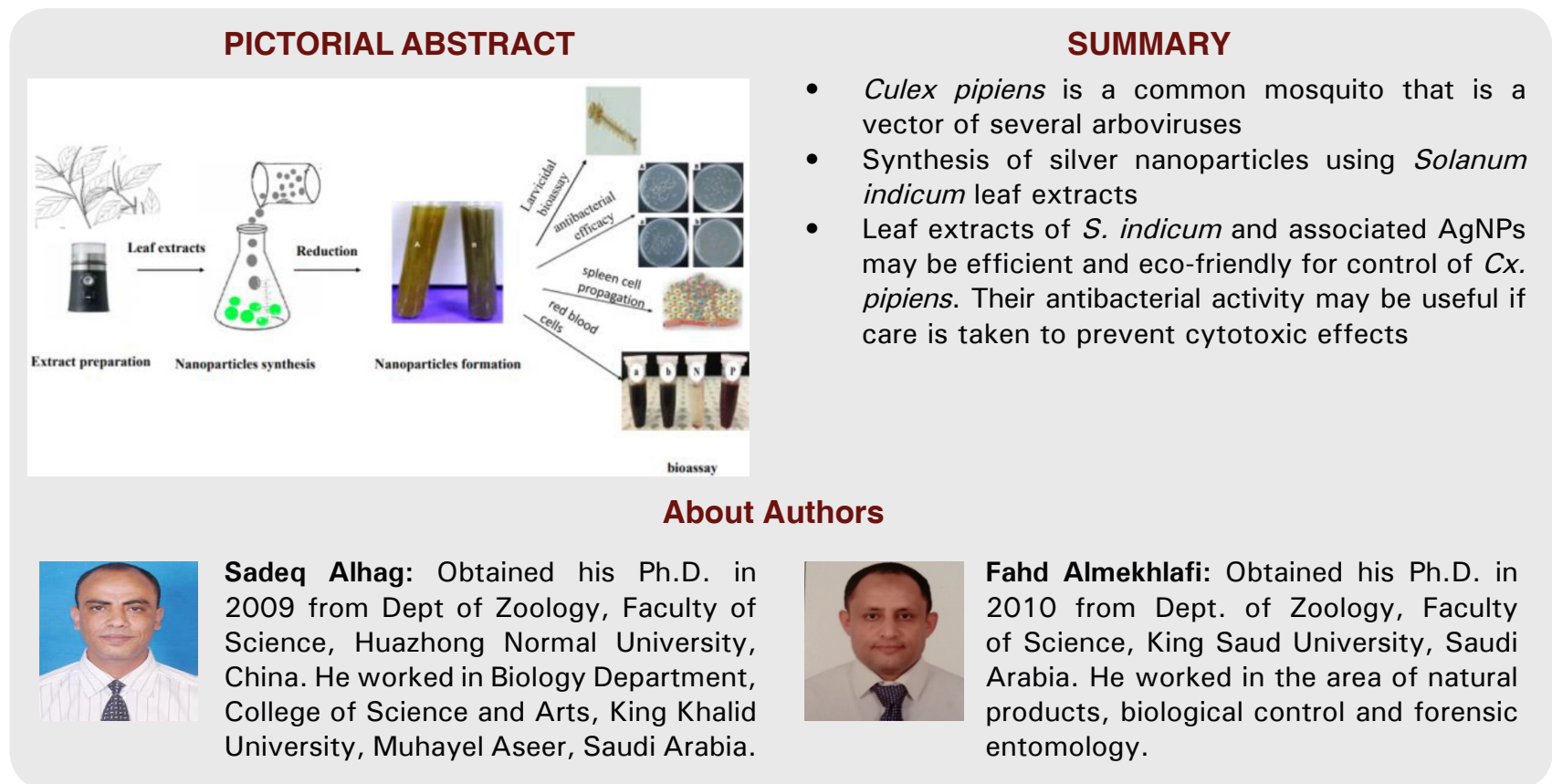

Cite this article: Alhag SK, Ghramah HA, AL-keridis LA, et al. Biogenic Synthesis of Silver Nanoparticles (AgNPs) using Solanum indicum Linn. Indian J of Pharmaceutical Education and Research. 2021;55(1s):s202-s208. 